\title{
An Overview about Beriberi Outbreaks in Brazilian and Portuguese Vincentian Institutions
}

\author{
C. S. Cunha, C. A. B. de Maria, J. O. Rodrigues Neto, C. S. Cunha, A. J. Teodoro, T. P. B. Lima
}

\begin{abstract}
Students and orphans from Brazilian and Portuguese Vincentian institutions suffered outbreaks of a unknown disease in the $19^{\text {th }}$ century, today called Beriberi. Primary cause was malnutrition, but part of the students did not present Beriberi. Our aim was to investigate the effect of malnutrition, as well as secondary factors (consumption of infusions, fasting and depression) in the etiology of Beriberi. Ingestion of thiamine (vitamin $B_{1}$ ) in both Caraça school and Asylum D'Ajuda was $815 \mu \mathrm{g} \mathrm{dia}^{-1}$ and $844 \mu \mathrm{g} \mathrm{dia}^{-1}$, respectively. Intake of vitamin $B_{1}$ was of $24 \%$ to $46 \%$ lower than that recommended by RDA. Consumption of infusions from Luxemburghia polyandra (congonha) and Camellia sinensis (black tea) rich in anti-thiamine polyphenols was responsible for degradation of above $25 \%$ of vitamin $B_{1}$. Prolonged religious fasting decreases food ingestion and it could aggravate hypovitaminosis. The harsh way of life in the Vincentian institutions may contribute to depression emergence in susceptible students going to causing food inappetence. In conclusion, malnutrition associated with consumption of infusion, religious fasting and depression could have triggered the Beriberi in part of the student body of both Caraça school and Asylum D'Ajuda.
\end{abstract}

Index Terms - malnutrition, consumption of infusion, depression and fasting.

\section{INTRODUCTION}

Brazil and Portugal experienced outbreaks of an unknown disease between 1850 and 1910, which affected young people from religious, charitable, and educational Vincentian orders. Primary symptoms were: weakness, muscle pain, peripherical motor impairments and paraplegia. The disease has later been called Beriberi, which is caused by several and chronic thiamine (vitamin $\mathrm{B}_{1}$ ) hypovitaminosis [1]. Lopes Filho [2] investigated subject and reported it seemed to be no associated exclusively with insufficient daily diet. However, he was unable to explain why only portion of students presented clinical picture of the disease.

Our present study focuses not only on malnutrition but also on possible secondary factors, such as regular consumption of infusions prepared from Camellia sinensis (black tea) and Luxemburghia polyandra (congonha), religious fasting and depression. Religious fasting and depression [3], [4] have been associated with decreasing in food ingestion. The occurrence of anti-thiamine compounds, such as, polyphenols, in plants infusions could degrade thiamine in gastrointestinal tract [5]. These secondary factors might be subjacent causes for only a certain portion of students had been affected by Beriberi. Two 19th century institutions were

Published on August 292020

C. S. Cunha, ITPAC, Brazil.

(corresponding e-mail: cunhacleize ${ }^{@}$ gmail.com)

C. A. B. de Maria, UNIRIO, Brazil.

J. O. Rodrigues Neto, UNIFOA, Brazil. investigated in this study, namely, the Caraça school (Brazil, 1858-1910) and Asylum D'Ajuda (Portugal, 1865). A better knowledge of what happened in the far past could help in understanding other outbreaks of Beriberi that have occurred in the past decade [6].

\section{Methodology: HistoricAl APPROACH}

The study adopted was historical to contextualize narrative. Some publications by both different authors and graduated secondary students from the Caraça school on everyday life were researched and used as source of consultation. Official documents and others sources of consultation were the basis for investigating the daily life of orphans in the Asylum D'Ajuda [7], [8]. The study presents two methodological approaches: qualitative and experimental.

The qualitative technique is based on documentary analysis (historical and current texts) and is carried out in three stages: preliminary analysis of material (reading, constitution of the theorical corpus, formulation of hypotheses), exploration of material (detailed analysis of material and selection) and treatment of results with subsequent interpretation.

The experimental technique was carried out from the survey of total phenolics in plant species used at the time, such as black tea (Asylum D'Ajuda) and congonha infusion (Caraça school). Data from the phenolic total in black tea were obtained from elsewhere [9]. There was not found any report about total phenolic composition in congonha infusion. Thus, it was carried out total phenolic analysis in congonha infusion with basis on previous reported method [10].

Several sources of consultation were obtained from following institutions: Colégio do Caraça, Parque Estadual do Itacolomi, CEMPLANT, Arcebispado de Mariana, Jardim Botânico do Rio de Janeiro, Missão Lazarista do Cosme Velho, Biblioteca Nacional do Rio de Janeiro, Real Gabinete Português de Leitura, Mosteiro de São bento, Hemeroteca Digital da Biblioteca Nacional Brasileira, Universidade Federal do Rio de Janeiro, Biblioteca da Universidade de São Paulo, Biblioteca da Universidade Federal do estado do Rio de Janeiro, Arquivo público Mineiro, sites de buscas como Pubmed, Scielo, Biblioteca Virtual de Saúde, EBSCO, gazeta Médica da Bahia e Google Scholar.

C. S. Cunha, UNIFOA, Brazil.

A. J. Teodoro, UNIRIO, Brazil.

T. P. B. Lima, UNIRIO, Brazil. 


\section{MALnUtrition, CONSUMPTION OF InfUsion, BERIBERI}

An dietary imbalance has been described in both school of the Caraça and Asylum D'Ajuda. Students from the school of the Caraça were boys [10] while orphans from the Asylum D'Ajuda were mostly girls [11]. Lopes Filho [2] presented an estimative of both caloric and vitamin $\mathrm{B}_{1}$ intake in school of the Caraça, which was round $1,727 \mathrm{kcal} \mathrm{dia}^{-1}$ and $580 \mu \mathrm{g}$ dia ${ }^{1}$, respectively. Content of vitamin $\mathrm{B}_{1}$ was $59 \%$ lower than that from recommended dietary allowance RDA, 1,500 $\mu \mathrm{g}$ $\mathrm{dia}^{-1}$ for boys [12]. But he did not associate with Beriberi, according to him, due to the difficulty judging amount of food consumed. Our study partially agreed with data from Lopes Filho [2]. Although our value for vitamin $\mathrm{B}_{1}\left(815 \mu \mathrm{g} \mathrm{dia}^{-1}\right)$ was higher, it was also insufficient, being $46 \%$ lower than that recommended by RDA [12]. Caloric intake was 2,839 $\mathrm{kcal} \mathrm{dia}^{-1}, \mathrm{ca} 64 \%$ higher than that found by Lopes Filho [2]. Inconsistencies between our results and those from Lopes Filho [2] may be attributed to fact that we have included other foods described in previous studies [13]-[15] which were not included by Lopes Filho [2]. There has not been any publication about consumption of vitamin $\mathrm{B}_{1}$ and caloric intake by orphans of the Asylum D'Ajuda until now. Their diet was hypocaloric $\left(1,820 \mathrm{kcal} \mathrm{dia}^{-1}\right)$ and intake of vitamin $\mathrm{B}_{1}\left(844 \mu \mathrm{g} \mathrm{dia}^{-1}\right)$ was closed to that found in school of the Caraça $\left(815 \mu \mathrm{g} \mathrm{dia}^{-1}\right)$. Female orphans ingested a value of vitamin $\mathrm{B}_{1} 24 \%$ lower than that recommended by RDA [12] $\left(1,100 \mu \mathrm{g} \mathrm{dia}^{-1}\right.$ for girls) [12]. Malnutrition was the primary factor responsible for outbreaks of Beriberi in abovementioned institutions. The disease on the other hand did not affect the entire student body. Furthemore, intake of vitamin $B_{1}$ was above of critical value of $200 \mu \mathrm{g} \mathrm{dia}^{-1}$, below which clinical signs may appear [16].

We investigated some secondary factors capable of further accentuating vit $\mathrm{B}_{1}$ deficiency triggering the Beriberi. Plant infusions were ingested daily in both Asylum D'Ajuda (black tea) and Caraça school (congonha infusion). According to Vimokensant (1982) [5], presence of polyphenols in black tea was capable of destroying $930 \mu \mathrm{g} \mathrm{dia}^{-1}$ of vitamin $\mathrm{B}_{1}$ per gram of tea (1\% solution) ingested. Consumption of fruits with at least $100 \mathrm{mg} \mathrm{dia}^{-1}$ of ascorbic acid (vitamin $\mathrm{C}$ ) has prevented degradation [17]. Orphans who consumed black tea, but not fruits rich in vitamin $\mathrm{C}$, at meals could have at a much greater risk of manifesting the Beriberi. Due to lack of data on total phenolics in congonha, we analysed total phenolics content in two replicates of the plant. The average value was $11.2 \pm$ $0.5 \mathrm{EAG} 100 \mathrm{~g}^{-1}$ sample. Our value was $c a$ three times lower than that found in green tea [9]. Since congonha leaf is not subjected to fermentation it is more appropriated to compare its anti-thiamine effect with that of green tea. Loss of $210 \mu \mathrm{g}$ dia $^{-1}$ of vitamin $B_{1}$ per gram of green tea ( $1 \%$ solution) has been previously reported [5]. Thus, students from the school Caraça when consuming $300 \mathrm{~mL} \mathrm{dia}{ }^{-1}$ (1\% solution) of congonha infusion may lose $26 \%$ of vitamin $B_{1}$ from the diet. An unbalanced diet plus consumption of infusions rich in polyphenols at meals was a favorable setting for the manifestation of Beriberi in part of student body.

\section{Religious FASTING, DEPRESSION, BERIBERI}

The practice of Christian ecclesiastical fasting was part of fervent and ingrained religious belief manifested in the mentality of remission of sins and salvation of the soul [18], [19]. Vincentian catholic order followed ascetically these precepts [20]. As Machado [21] described: "In schools governed by Vincentian order, a complicated system of readings and spiritual exercises, fasting and obligatory confessions, sermons, blessings, "novenas", sacra via, constitute all moral education." Food deprivation during fasting could act as additional secondary factor for worsening vitamin $\mathrm{B}_{1}$ deficiency. Fasting was used as a punishment for disobedient students, so some students were fasting more than others [22].

Depression is a serious mental disorder, not well known in the 19th century, with unpleasant chronic consequences, among them, irritability, persistent feeling of hopelessness and lack of appetite [23]. The immutable teaching practice in a secluded place and separated from family, religious inculcation and a radical change of environment may facilitate the emergency of depression. In addition, there were peculiar characteristics in each institution. Asylum D'Ajuda received orphans from the outbreaks of scourges of small pox and yellow fever in Portugal. School of the Caraça was geographically located in an elevated, remote and difficult to access region in Brazil. These characteristics had made the environment conducive to depression development. Andrade Lima [10] described: "....after the school semester, there was a formal ceremony for reading the grades. The best students were applauded and the worst, booed by their colleagues....". Patroni [24] reported: "....we have lunch next to a torrent that fell from the stones, and whose whisper, increased the terror of a sad and hideous loneliness. " ... the idea of the missions was not particularly festive.... they were foreigners, .......one of them were up to the pulpit and preached,....the horrors of hell, the misery of the soul in mortal sin....the sweetness of suffering and being humiliated...." [25] These absurdities certainly influenced some students with low power of reflection or even with a family heritable of faith without discussion. Therefore, a part of the most susceptible student could have symptoms of depression, due to a life of seclusion and deprivation of all kinds, especially freedom. Depression may cause food inappetence and thus accentuate the deficiency of vitamin $\mathrm{B}_{1}$.

\section{FinAl CONSIDERATIONS}

How difficult it is to tell the story of malnutrition in isolated groups, as is the case in this study. But it is important to do it so in order to avoid that inhuman conditions simply arise in today's times. These outbreaks were not accidental, but a mixture of ignorance and cruelty. The proof of this is that priests and assistants did not manifest the disease because their alimentation was different from that of the students and orphans. Malnutrition associated with lack of knowledge about anti-thiamine factors in plants as well as Vincentian ascetic ideals with intermittent fasting and stimulation of depression could be the cause of Beriberi outbreaks in both school of Caraça and Asylum D'Ajuda. 


\section{REFERENCES}

[1] S. Dhir, S, M. Tarasenko, E. Napoli, C. Giulivi. "Neurological, Psychiatric, and Biochemical Aspects of Thiamine Deficiency in Children and Adults". Front. Psychiatry, vol.10, pp.207-222, 2019.

[2] J. D. Lopes Filho, O Beribéri no Caraça. Tese de Doutorado da Universidade São Paulo (USP). São Paulo, 1998.

[3] J. F. Carrato, As Minas Gerais e os Primórdios do Caraça; São Paulo: Companhia Editora Nacional; 1963.

[4] N. M. Pereira, G.T. Fraga, "Vestígios do Passado: documento e ensino da história". Anais Eletrônicos do IX Encontro Nacional dos Pesquisadores do Ensino de História 18, 19 e 20 de abril de 2011. Florianópolis, 2011. Acesso em 2019.

[5] S. Vimokesant, "Beribéri caused by antithiamin factors in food and its prevention," Annals of New York Academy of Sciences, vol. 50, pp.123$136,1982$.

[6] H. Barennes, K. Sengkhamyong, J. P. René, M. Phimmasane, Beriberi (Thiamine Deficiency) and high infant mortality in northern laos. Plos: Neglected Tropical Diseases, 2015

[7] M. I. C. S. Padilha, M. S. Borenstein, "O método de pesquisa histórica na enfermagem," Texto e Contexto Enferm. Florianópolis, vol. 14, no.4, pp. 575-84, 2005.

[8] D. M. Albuquerque Junior, História: a arte de inventar o passado (ensaios de teoria da história), 1st ed. Curitiba: Prismas, 2017.

[9] V. P. Pereira, F. J. Knor, J. C. R. Velloza, F. L. Beltrame, "Determinacão de compostos fenólicos e atividades anti-oxidantes dos chás verde, preto e branco de Camellia Synensis," Revista Brasileira de plantas medicinais [on line], vol. 16, no.3, pp. 490-498, 2014.

[10] M. G. Andrade, A educação exilada: Colégio do Caraça, 1st ed. Belo Horizonte: Autêntica, 2000

[11] J. A. Pintassilgo, “A Educação Doméstica nos Asilos Femininos. O exemplo do Asilo D. Pedro V de Lisboa na transição do século XIX para o século XX," Revista História \& Perspectivas, vol.1, no.38, mar 31, 2009.

[12] Recommended Dietary Allowances, "National" US Research Council, 10st ed. Washington: National Academies Press, 1989.

[13] J. F. Carrato, As Minas Gerais e os Primórdios do Caraça, 1st ed. São Paulo: Companhia Editora Nacional; 1963.

[14] E. Frieiro, Feijão, angu e couve: ensaio sobre a comida dos mineiros, 1st ed. Belo Horizonte: Itatiaia, 1982.

[15] J. Salles, Se não me falha a memória, 2st ed. São Paulo: Instituto Moreira Salles, 1993.

[16] M. K. Horwitt, E. Liebert, O. Knisler, P. Wittman, "Investigations of human requeriments for B- complex vitamins. Bulletin of the National Research Council No. 166," Report of the Committee on nutritional aspects of ageing, food and nutrition board, Division of biology and agriculture, National academy of sciences, Washington, D.C. $106 \mathrm{pp}$. 1948.

[17] B. Panijpan, K. Rungruangsak-Torrisen, P. Vilartsankdanon, S.L. Vimokesant, "Resolution of the initial phase controversy in the thiamine-polypenol reaction," International Journal for Vitamin and Nutrition Research. Reprint 48, no.3, pp. 262-267, 1978. Available: http://www.researchgate.net.publication.22431693.

[18] L. J. Moga, Liturgie, eschatologie: une approcheorthodoxe. Communio, vol.39, no.3, pp.11-24, 2014.

[19] J. de Varazze, Legenda Áurea: Vidas dos santos. São Paulo: Schwarkcz, 2018.

[20] P. Coste, Saint Vincent de Paul: Entretien saux missionnaires. Tome XI.p.XL- 1. Available: cmission.fr/index/php/medias/.

[21] J. M. Machado, Educação physica, moral e intelectual da mocidade do Rio de Janeiro e sua influência sobre a saúde. Tese de Doutorado apresentada à Faculdade de Medicina do Rio de Janeiro. Rio de Janeiro: Typ. De G Leuzinger e filhos, 1875.

[22] P. L. Vasconcelos, Antônio Conselheiro por ele mesmo: Apontamentos dos preceitos da divina lei de Nosso Senhor Jesus Cristo para a salvação dos homens. São Paulo: É realizações, 2017.

[23] American Academy of Child and Adolescent Psychiatry, Depression in children and teens. Available: https://www.aacap.org/AACAP/Families_and_Youth/Facts_for_Famili es/FFF-Guide/The-Depressed-Child-004.aspx.

[24] F. A. Patroni, F.A. A viagem de Patroni pelas províncias brasileiras: de Ceará, rio de S. Francisco, Bahia, Minas Gerais e Rio de Janeiro, nos anos de 1829 e 1830, dividida em quatro partes. Brasília: Senado Federal, 2015.

[25] C. D. Andrade, Contos de Aprendiz, 1st ed. São Paulo: Cia. das Letras, 2012.

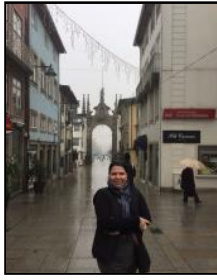

Ms. Cunha was born in Rio de Janeiro, Brazil in 1973.

She holds a Master of Science degree from UniFOA in 2015 and a $\mathrm{PhD}$ in Science from UniRIO, Rio de Janeiro, Brazil. She is an assistant professor of medicine at ITPAC State of Minas Gerais, Brasil.

Ms. Cunha is a permanent member of the Board of section of Minas Gerais, Brazil. Physical Therapy and Occupational Therapy 